\title{
TARI DIBINGI
}

\section{sebuah upaya penggalian data AWAL TARIAN TRADISIONAL YANG TERANCAM PUNAH DI KABUPATEN PESISIR BARAT, LAMPUNG}

\author{
DIBINGI DANCE: \\ AN EFFORT IN SEARCHING OF PREVIOUS DATA \\ OF ENDANGERED TRADITIONAL DANCE IN PESISIR BARAT REGENCY
}

\author{
Irvan Setiawan \\ Peneliti Utama Balai Pelestarian dan Nilai Budaya Bandung \\ Jl. Cinambo No. 136 Ujungberung - Bandung \\ e-mail: kamaliasetiawan@yahoo.co.id
}

\begin{abstract}
Abstrak
Kekayaan budaya Indonesia yang sangat beragam pada saat ini sedang menghadapi tantangan pelestarian akibat pengaruh budaya modern yang semakin mewabah pada sebagian besar generasi muda. Kesenian tradisional, salah satunya, merupakan unsur budaya yang sebenarnya dapat bertahan dengan cara mengkolaborasikan dengan gerak, tata panggung ataupun suara dari kesenian lainnya yang menjadi senjata cukup ampuh minimal untuk mempertahankan jumlah peminatnya. Lain halnya dengan kesenian tradisional yang masih erat dalam memegang teguh prosedur adat seperti halnya tari dibingi sebagai sebuah tari tradisional yang ada di Kabupaten Pesisir Barat Provinsi Lampung. Ketentuan untuk mengadakan tahapan baik sebelum dan setelah pergelaran, membuat seniman kesulitan untuk mempergelarkan tari dibingi. Penelitian yang menggunakan metode deskriptif kualitatif ini merupakan sebuah penggalian data awal sebagai salah satu upaya memperkenalkan kembali keberadaan tari dibingi di tengah masyarakat khususnya masyarakat di Kabupaten Pesisir Barat.
\end{abstract}

Kata kunci: Tari dibingi, Pesisir Barat, Lampung.

\begin{abstract}
Indonesia's diverse cultural richness is currently facing the challenge of conservation due to the increasingly prevalent modern culture in most of the younger generation. Traditional art is one of them, which is an element of culture that can actually survive by collaborating with movements, stage performance, or the sound of other arts. It becomes a minimal powerful weapon to maintain the number of interested ones. It is different with the traditional arts that are still closely held to the traditional procedures, such as Dibingi Dance as a traditional dance in Pesisir Barat Regency, Lampung Province. The stages of rule to perform Dibingi Dance, both before and after, create difficulties for the artists. This qualitative descriptive research is an initial data extraction that attempts to reintroduce the existence of Dibingi Dance in the community, especially the people in Pesisir Barat Regency.
\end{abstract}

Keywords: Dibingi Dance, Pesisir Barat, Lampung. 


\section{A. PENDAHULUAN}

Perjalanan sebuah kesenian tradisional dalam menghadapi dunia seni modern yang saat ini tengah naik daun terkadang dilalui dengan tertatih-tatih untuk tetap berupaya tampil di hadapan publik. Disain yang ditampilkan dalam sebuah karya seni tradisional kerap dipandang sebagai sebuah kekunoan oleh para disainer seni modern dan hal ini tentunya akan sangat menyulitkan kebertahanan seni tradisional. Kesulitan para desaigner seni tradisional dalam mengembangkan seni tradisional dalam upaya mensiasati kebertahannya di antaranya disebabkan ada pakem-pakem yang pada beberapa kesenian tradisional tertentu tidak boleh dilanggar. Terlebih lagi apabila seni tradisional yang hendak dikolaborasikan atau dipadukan dengan bentuk seni lainnya sangat kental dengan aroma sakral. Hal mana yang oleh para sesepuh adat dikatakan sangat ditabukan untuk dikreasikan.

Perkara apakah ditabukan atau tidak, seni merupakan sebuah tindakan sosial yang menuntut untuk dapat dinikmati baik dari segi estetika, nilai, dan makna yang terkandung dalam sebuah pertunjukan seni. Unsur sakral yang ada dalam beberapa kesenian tradisional mengingatkan pada konsep keluhuran para karuhun yang mengajarkan berbagai jenis etika yang menyangkut pola kehidupan manusia. Upaya untuk mengungkap keluhuran tersebut diwujudkan dalam sebuah karya seni dengan cara menampilkan sisi-sisi keluhuran ajaran para karuhun melalui unsur gerak dan suara yang dipadukan dengan asesoris tertentu sehingga menunjukkan sebuah penghormatan berikut perwujudan ajaran yang disampaikan oleh karuhun (Rosyadi, 2016: 399-401).

Saat ini, dari pengamatan yang dilakukan tampak bahwa unsur sakral dalam sebuah pergelaran seni sedikit demi sedikit sudah mulai kehilangan rohnya. Upaya antisipasi dalam bentuk penyesuaian dengan keinginan penonton yang sudah terimbas oleh pergelaran kesenian modern membuat pergelaran seni tradisional yang mengandung unsur sakral sedikit demi sedikit mengalami pergeseran baik dari segi waktu, kostum, maupun unsur gerak dan suara. Beberapa karya seni tradisional yang mengandung unsur sakral yang tetap mempertahankan prosedur ketradisionalannya saat ini sudah tentu akan kehilangan penonton, bahkan pelaku seni itu sendiri. Salah satu yang sudah terjadi saat ini adalah keberadaan pergelaran tari dibingi yang ada di Kabupaten Pesisir Barat Provinsi Lampung. Tari dibingi merupakan sebuah tari yang mengandung unsur sakral dan hanya dipergelarkan dalam sebuah pesta pernikahan. Dari informasi yang diperoleh, saat ini hanya ditemukan satu maestro tari dibingi bernama berinisial HY bertempat tinggal di Desa Penengahan Laay, Kec. Karya Penggawa, Kab. Pesisir Barat yang saat ini berusia 76 tahun (lahir tahun 1942). Dalam usia tuanya, beliau masih dapat memperagakan tari dibingi meskipun dengan gerak tari yang sudah tidak selincah dikala muda. Beruntung saat ini HY memiliki satu orang penerus dari kalangan generasi muda yang berminat dan mulai menguasai tari dibingi berinisial $\mathrm{P}$.

\section{B. METODE PENELITIAN}

Penelitian ini dilakukan untuk mendeskripsikan pergelaran tari dibingi laki-laki yang diperagakan oleh $\mathrm{HY}$ dan $\mathrm{P}$ dengan menggunakan metode kualitatif. Data yang dikumpulkan lebih banyak merupakan data primer mengingat data sekunder yang secara khusus membahas tari dibingi sangat sedikit atau bahkan tidak ada sama sekali. Data sekunder lebih diarahkan pada instansi dan lembaga yang itupun hanya dipergunakan untuk mendeskripsikan gambaran umum lokasi penelitian.

Sementara itu, pencarian data primer dilakukan dengan mewawancarai satu satunya maestro seni tari dibingi berinisial HY. Beberapa alat pendukung yang sangat berguna dalam pencarian data primer 
adalah voice recorder, kamera, dan handycam. Ketiga alat tersebut berperan penting dalam proses pencarian data primer. Hal ini disebabkan pergelaran tari dibingi membutuhkan data baik dalam bentuk suara (informan), dan visualisasi gerak Tari dibingi.

Tulisan mengenai tari dibingi bermaksud untuk menggali kembali informasi salah satu kekayaan budaya Kabupaten Pesisir Barat, mengingat jenis tari dibingi masuk dalam tarian adat yang termasuk disakralkan atau dikeramatkan. Oleh karena itu, tari dibingi dapat dikatakan sudah hampir punah karena salah satu syaratnya adalah harus ada perhelatan baik sebelum atau setelah pergelaran tari dibingi. Meskipun saat ini sudah mulai ada upaya pelestarian tari tradisional lampung. Khusus tari dibingi yang ada di Kabupaten Pesisir Barat masih tergolong spesifik dan kerap memegang teguh prosedur pelaksanaannya.

Beberapa batasan yang menjadi ruang lingkup penulisan ini yaitu: seni tari, sakral, dan terancam punah.

- Seni Tari

Menurut Jazuli (dalam Ratih: 2001: 69), seni tari adalah sebuah seni yang berfungsi sebagai:

1. Tari sebagai sarana upacara merupakan media persembahan atau pemujaan terhadap kekuatan gaib yang banyak digunakan oleh masyarakat yang memiliki kepercayaan animisme (roh-roh gaib), dinamisme (bendabenda yang mempunyai kekuatan), dan totemisme (binatang-binatang yang dapat mempengaruhi kehidupan) yang disajikan dalam upacara sakral.

2. Tari sebagai hiburan dimaksudkan untuk memeriahkan atau merayakan suatu pertemuan. Tari yang disajikan dititikberatkan bukan pada keindahan geraknya, melainkan pada segi hiburan.

3. Tari sebagai pertunjukan, yaitu tari yang bertujuan untuk memberi pengalaman estetis kepada penonton.
Tari ini disajikan agar dapat memperoleh tanggapan apresiasi sebagai suatu hasil seni yang dapat memberi kepuasan pada mata dan hati penontonnya.

4. Tari sebagai media pendidikan, yaitu tari yang bersifat untuk mengembangkan kepekaan estetis melalui kegiatan berapresiasi dan pengalaman berkarya kreatif.

- Sakral

Menurut Kamus Bahasa Indonesia, sakral adalah suci; keramat bagi penduduk setempat (Tim Penyusun Kamus Pusat Bahasa, 2008: 1246). Sejalan dengan arti sakral tersebut, sakral dalam pengertian ini lebih merujuk pada kehadiran seni yang memiliki hubungan erat dengan kepatuhan kepada adat leluhur yang dalam hal ini diwarisi oleh para ketua adat Saibatin beserta masyarakat pendukungnya.

\section{- Terancam Punah}

Pengertian terancam punah merujuk pada formulir Warisan Budaya Takbenda yang dikeluarkan oleh UNESCO (Waluyo, 2009: 24) untuk melihat kriteria keberadaan sebuah karya budaya yang terbagi menjadi lima bagian, yaitu: 1) sedang berkembang; 2) masih bertahan; 3) sudah berkurang; 4) terancam punah; dan 5) Sudah punah/tidak berfungsi lagi dalam masyarakat. Melihat lima kriteria tersebut maka dapat diartikan bahwa terancam punah adalah setingkat lebih rendah di bawah sudah berkurang namun berada di atas sudah punah karena karya budaya yang dimaksud masih ada dan masih memiliki maestro/pelaku budaya.

\section{HASIL DAN BAHASAN}

\section{Gambaran Umum Lokasi Penelitian}

Pesisir Barat merupakan kabupaten ke-13 di Provinsi Lampung. Sebuah kabupaten yang merupakan hasil pemekaran dari Kabupaten Lampung Barat melalui pengesahan Undang-undang Nomor 22 Tahun 2012 tentang Pembentukan Kabupaten Pesisir Barat 
Provinsi Lampung pada tanggal 25 Oktober 2012. Peresmian Kabupaten Pesisir Barat dilakukan pada tanggal 22 April 2013.

Wilayah Kabupaten Pesisir Barat terbagi menjadi 11 Kecamatan, yaitu:

1. Bengkunat Belimbing

2. Bengkunat

3. Ngambur

4. Pesisir Selatan

5. Krui Selatan

6. Pesisir Tengah

7. Way Krui

8. Karya Penggawa

9. Pesisir Utara

10. Lemong

11. Pulau Pisang

Peta 1. Peta Administrasi Kabupaten Pesisir Barat.

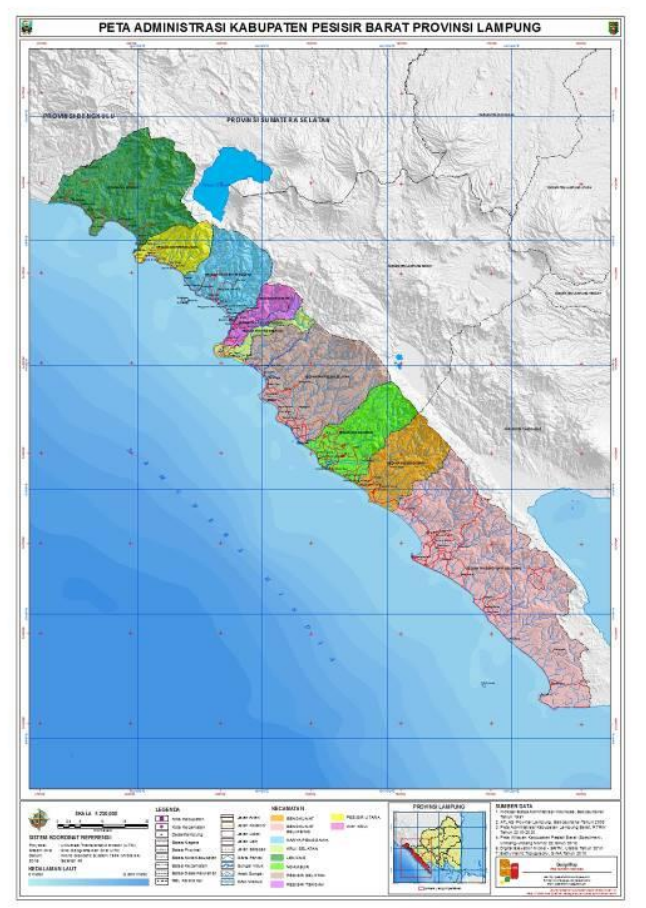

Sumber: petatematikindo.wordpress.com, 2017

Kabupaten Pesisir Barat terletak di bagian paling Barat Provinsi Lampung dengan titik koordinat $5^{\circ} 21^{\prime} 52^{\prime \prime}-5^{\circ} 28^{\prime} 62$ LS dan : $105^{\circ} 48^{\prime} 20^{\prime \prime}-105^{\circ} 48^{\prime} 24^{\prime \prime}$ BT. Batasan wilayah berdasarkan arah mata angin adalah sebagai berikut:
1. Sebelah Utara berbatasan dengan Kabupaten Kab. Kaur Selatan Prov. Bengkulu.

2. Sebelah Timur berbatasan dengan Kabupaten Lampung Barat.

3. Sebelah Selatan berbatasan dengan Kabupaten Tanggamus

4. Sebelah Barat berbatasan dengan Samudra Hindia.

Kabupaten Pesisir Barat secara umum termasuk kedalam dataran rendah yang diapit dalam pegunungan Bukit Barisan sebelah Timur dan samudra Indonesia Sebelah Barat. Daerah ini mempunyai ketinggian $15 \mathrm{~m}$ di atas permukaan laut (DPL) dengan bentuk wilayah terdiri dari: dataran sampai berombak $25 \%$, berombak sampai berbukit $10 \%$, berbukit sampai bergunung $65 \%$. Topografi yang sulit dan kesuburan tanah yang relative rendah menjadi faktor pembatas dalam melakukan intensifikasi pertanian. Di sepanjang dataran pantai banyak sawah yang dicetak sedangkan daerah perbukitan didominasi oleh hutan Damar. Kondisi Hutan damar cukup subur mengingat iklim yang sangat membantu, yaitu beriklim tropis dengan musim hujan dan musim kemarau berganti sepanjang tahun dengan temperatur rata-rata $31^{\circ} \mathrm{C}$.

Jumlah penduduk ${ }^{1}$ menurut data Badan Pusat Statistik (BPS) Kabupaten Pesisir Barat Tahun 2017 berdasarkan jenis kelamin berjumlah 138.601 perempuan dan 157.088 laki-laki. Sementara untuk klasifikasi berdasarkan usia, sekitar 27,99 $\%$ berusia $0-14$ tahun, $68,50 \%$ berusia antara $15-64$ tahun, dan $3,51 \%$ berusia 65 tahun ke atas.

Masyarakat Kabupaten Pesisir Barat sebagian besar merupakan masyarakat Suku Lampung Saibatin. Saibatin adalah suku lampung yang banyak mendiami

1 Penduduk adalah semua orang yang telah berdomisili selama 6 bulan atau lebih dan/atau mereka yang berdomisili kurang dari 6 bulan tetapi bertujuan menetap (BPS Kabupaten Pesisir Barat, 2016: 9) 
wilayah pesisir Provinsi Lampung. ${ }^{2}$ Dalam masyarakat Lampung Saibatin terbagi dalam marga-marga. Sabaruddin (2012: 24) mencatat ada sekitar 44 marga Lampung Saibatin, yaitu:

Tabel 1: Nama Marga Lampung Saibatin

\begin{tabular}{llll}
\hline No Nama Marga & No & Nama Marga \\
\hline 1 & Dantaran & 23 & Liwa \\
\hline 2 & Pesisir Rajabasa & 24 & Kembahang \\
\hline 3 & Marga Ratu & 25 & Batu Bekhak \\
\hline 4 & Legun & 26 & Kenali \\
\hline 5 & Teluk Betung & 27 & Pulau Pisang \\
\hline 6 & Menanga & 28 & Wai Tenong \\
\hline 7 & Ratai & 29 & Suwoh \\
\hline 8 & Punduh & 30 & Bengkunat \\
\hline 9 & Pedada & 31 & Belimbing \\
\hline 10 & Badak & 32 & Ngambor \\
\hline 11 & Putih & 33 & Tenumbang \\
\hline 12 & Limau & 34 & Wai Napal \\
\hline 13 & Kelumbayan & 35 & Pasar Krui \\
\hline 14 & Pertiwi & 36 & Ulu Krui \\
\hline 15 & Way Lima & 37 & Bandar \\
\hline 16 & Gunung Alip & 38 & Pedada \\
\hline 17 & Benawang & 39 & La'ai \\
\hline 18 & Buai Belunguh & 40 & Way Sindi \\
\hline \multirow{2}{*}{19} & Way Ngarip & Semong & Pugung \\
& Semong & & Tampak \\
\hline 20 & Pematang Sawa & 42 & Pugung \\
\hline 21 & Melinting & 43 & Pugung Mengahan \\
\hline 22 & Sukau & 44 & Ngaras \\
\hline
\end{tabular}

Sumber: Sabaruddin, 2012: 85.

Beberapa jenis kekayaan budaya yang ada di Kabupaten Pesisir Barat terdiri dari kuliner tradisional, seni musik tradisional, seni tari tradisional, dan penganan tradisional.

\footnotetext{
${ }^{2}$ Masyarakat Lampung terbagi menjadi dua kelompok adat, yaitu Saibatin dan Pepadun. Pepadun merupakan suku Lampung yang banyak mendiami daerah pedalaman atau daerah dataran tinggi Lampung. Berdasarkan sejarah perkembangannya, masyarakat Pepadun awalnya berkembang di daerah Abung, Way Kanan, dan Way Seputih (Pubian).
}

Kuliner Tradisional:

- Sate Ikan Tuhuk

- Sop Ikan Tuhuk

- Gulai Bebat

- Gulai Paku

- Gulai Bung

- Khetak Khenai Sumsum Belulang

- Sekhok Pulang Tiyung

- Sambal Gedang (Akhakhu Gedang)

- Gulai Kekhita

- Gulai Taduk

Penganan tradisional:

- Buak Tat

- Cucokh Mandan

- Selimpok Bungking

- Cucokh Bekhak

- Jala Bia

- Kacang Tujin

Tradisi Lisan:

- Muayak

- Sagata

- Hahiwang

Seni Musik Tradisional:

- Hadro

- Bedikekh

- Musik Gambus

- Gamolan Balak

Tari Tradisional:

- Tari Mukek Iwa Krui

- Tari dibingi

- Tari Nyambai

- Tari Hadro

- Tari Batin

- Tari Memadian

\section{Kemunculan Tari dibingi}

Kemunculan tari dibingi tidak dapat dipastikan tanggalnya. Namun demikian, menurut penuturan informan, keberadaan Tari dibingi dikaitkan masa penjajahan Inggris di wilayah tersebut, yaitu pada tahun 1912 tatkala wilayah perbatasan Bengkulu hingga Ujung Belimbing (wilayah Krui) masih di bawah jajahan Inggris. Pada tahun 1914 terjadi sebuah perjanjian antara Belanda dengan Inggris. 
Isi perjanjian tersebut di antaranya pertukaran wilayah jajahan. Belanda memberikan wilayah jajahannya di Serawak kepada Inggris dan menukarkannya dengan wilayah Krui hingga ke Bengkulu. Dengan demikian dapat dikatakan bahwa tari dibingi sudah ada sejak tahun 1912.

\section{Peraturan Adat Tari dibingi}

Kesakralan dalam bentuk kepatuhan kepada adat membuat tari dibingi tidak dikeluarkan atau dipamerkan kalau tidak ada proses yang dilaksanakan sebelum dan setelahnya. Beberapa syarat yang harus dilakukan adalah:

1. Menyembelih kerbau/sapi

Pelaksanaan Irau (perhelatan) tidak akan sah apabila tidak menyembelih kerbau atau sapi. Dahulu, objek yang disembelih untuk prosesi perhelatan adalah perawan. ${ }^{3}$ Setelah itu baru bisa diselenggarakan tari dibingi. Seiring berjalannya waktu, objek penyembelihan kemudian diganti menjadi hewan kerbau atau sapi.

2. Impun, yaitu sebuah permusyawarahan dari para ketua adat.

Di dalam impun beberapa kesepakatan yang harus dilaksanakan dalam gelar tari dibingi. Tempat melakukan impun dinamakan kelasa, yaitu semacam tarub lengkap dengan tabea (atap) dan diberi aksesoris bunga dan daun kelapa.

${ }^{3}$ Dalam Kamus Teologi, persembahan biasa disebut korban, hadiah, dan upeti. Tujuan dari persembahan ini adalah agar sebuah ritual dapat berjalan dengan lancar dan memberikan keyakinan kepada manusia bahwa hidup mereka setelah melakukan ritual akan aman, tenram, dan bahagia (R. Soedarsono, 1988: 54) Sementara itu, C. Barth mengartikan bahwa sebuah ritual berbentuk pengorbanan dimaksudkan sebagai sebuah persekutuan antara si pelaku ritual dengan dewa. Sang korban diibaratkan sebagai sebuah tanda takluk dan penghormatan agar apa yang diinginkan pemohon (pelaku ritual) dapat dikabulkan (C. Barth, 1970: 302).
Peserta impun perempuan biasanya mengenakan cadar berwarna merah. Menandakan bahwa ada sebuah pemisahan atau menjaga jarak dengan kaum lelaki yang juga menjadi bagian dari peserta impun. Setelah permusyawarahan dalam impun selesai dan menyepakati beberapa peraturan terkait tari dibingi, besok malamnya baru dilaksanakan tari dibingi.

Pembicaraan dalam impun tidak terfokus pada pergelaran tari dibingi saja. Di dalam impun turut juga dimusyawarahkan seperihalnya dengan pedandanan lapahan di bah/arakarakan pengantin, yang meliputi empat hal, yaitu: penetap imbokh; lampit pesirehan; payan dan pedang; payung 2 buah; dan bendera umbul-umbul;

3. Menyediakan kue

Kue disediakan dalam sebuah proses yang dinamakan Sapkoy Na'bay. $\mathrm{Na}$ 'bay adalah orang dari tempat lain yang pergi ke suatu tempat dengan suatu keperluan. Sediaan kue yang diberikan dalam sebuah perhelatan terdiri dari berbagai jenis dan ditaruh dalam nampan minimal berjumlah delapan buah.

4. Nayuh/penayuhan, yaitu sebuah pesta adat yang diadakan keluarga besar untuk merayakan sebuah momen adat, seperti pesta pernikahan, khitanan anak, mendirikan rumah, pesta panen dan Nettah Adoq. Namun khusus bagi masyarakat Saibatin, nayuh secara khusus diperuntukan pada pesta pernikahan.

Tingkat kemeriahan sebuah pesta pernikahan tergantung dari kondisi ekonomi dan status adat mempelai. Zaman dahulu apabila ada kerabat raja yang menyelenggarakan pesta pernikahan sudah sewajarnya dilaksanakan secara meriah. Bahkan, beberapa benda pusaka akan diperlihatkan dalam pesta pernikahan tersebut. 
Tari dibingi tidak bisa dicampur antara laki dan perempuan. Apabila satu group tari dibingi perempuan maka seluruh anggotanya adalah perempuan. Status penari seharusnya bujang atau gadis. Jumlah penari adalah tetap yaitu dua atau empat orang. Dengan kata lain bahwa tari dibingi dimainkan dalam jumlah genap. Pespektif gender yang menggolongkan antara penari perempuan dan penari lakilaki dalam tari dibingi menurut Elizabeth Eviota dalam Putraningsih (2006: 21) dilatarbelakangi oleh adanya sebuah relasi sosial antara perempuan dan laki-laki. Gender merupakan sebuah acuan yang memiliki makna sosial, budaya dan biologis. Seiring dengan kemajuan zaman, persepsi gender menurut Susanti (2000, 1 4) dapat berubah karena adanya perubahan ideologi, ekonomi, adat, agama, dan sosial budaya, etnik, waktu, tempat, dan kemajuan iptek.

\section{Peralatan}

Tari dibingi adalah salah satu tahapan dalam upacara Nayuh sebelum pergelaran tari kipas. Berbeda halnya dengan tari kipas yang menggunakan alat tari berupa kipas, tari dibingi, meskipun dalam beberapa gerakan ada yang sepertinya - menirukan gerak tangan yang sedang mengipas, namun tari ini diperagakan hanya menggunakan gerakan tangan. Adapun alat musik yang diperlukan dalam pentas tari dibingi di antaranya gelintang, rebana, dan gung (gong).

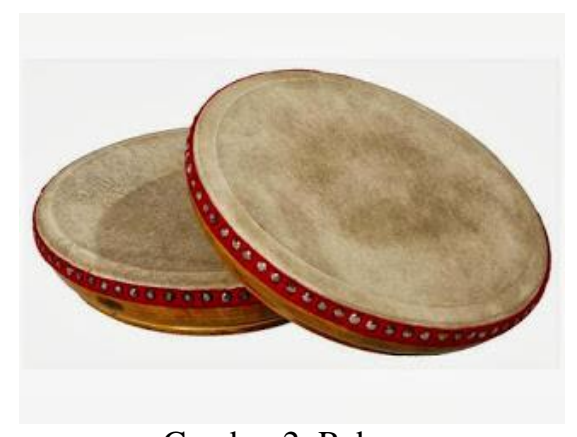

Gambar 2. Rebana

Sumber: yosuasr.it.student.pens.ac.id/ Projek\%20Web/kompang.html

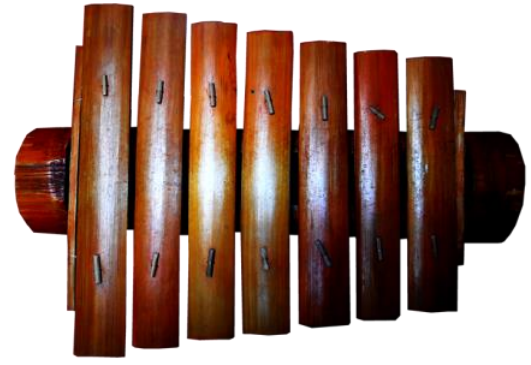

Gambar 3. Gulintang

Sumber: www.pengetahuandanteknologi. com/2016/09/artikel-tentang-alunan-syahdugamolan.html

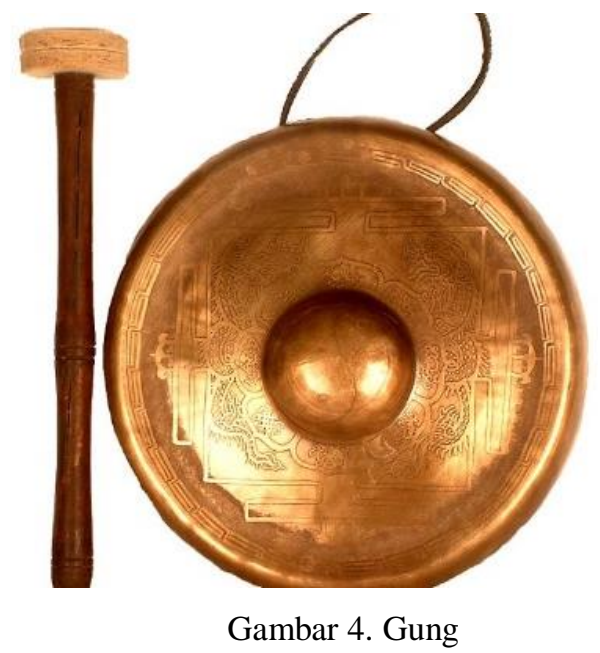

Sumber: www.carabermainalatmusik.com/carabermain-.ende/

Peralatan tersebut telah disediakan oleh panitia, yaitu panitia penyelenggara pesta pernikahan yang dipimpin oleh seseorang yang dinamakan Pang Tuha. Dalam sebuah pesta pernikahan pada masyarakat Lampung umumnya ada kebiasaan untuk membentuk sebuah kepanitiaan yang diketuai oleh seorang Pang Tuha.

\section{Pakaian}

Penari laki-laki mengenakan kopiah, baju putih panjang, celana panjang berwarna hitam. Di pinggang dililitkan sarung yang dilakukan dalam dua jenis, yaitu sarung gantung dan serong gantung. Sarung gantung, yaitu sarung yang dilipat 
dan dililitkan ke lingkar pinggang hingga hampir mendekati lutut. Jenis sarung yang digunakan biasanya bermotifkan air mas. Sementara itu, untuk jenis serong gantung, cara pemakaian adalah sama dengan sarung gantung namun agak diserongkan baik ke kiri ataupun ke kanan. Dalam adat istiadat Pesisir Barat, jenis lilitan sarung yang diwajibkan untuk perkawinan adalah jenis lilitan sarung gantung.

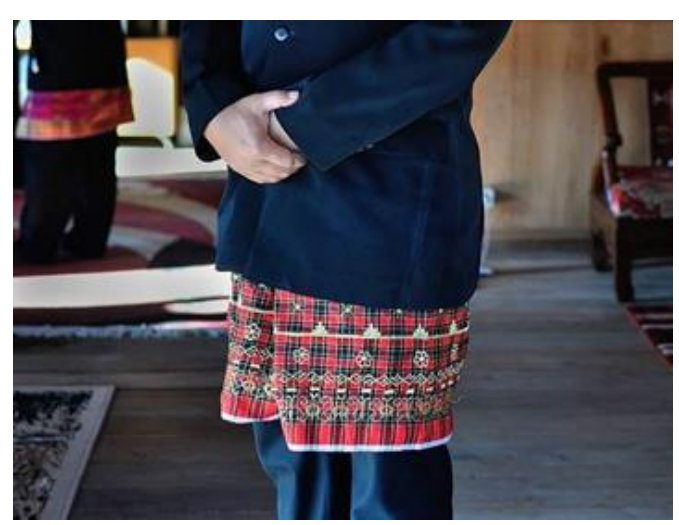

Gambar 5. Motif Sarung Gantung Sumber: Saliwa, 2017.

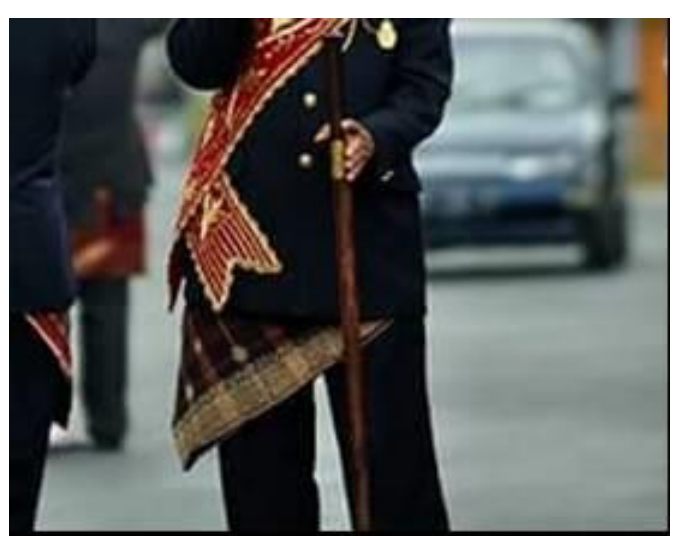

Gambar 6. Motif Serong Gantung Sumber: Saliwa, 2017.

Penari perempuan mengenakan baju kebaya dengan warna bebas. Bagian bawah mengenakan sarung yang dililitkan dengan panjang hingga mencapai tumit penari. Bagian pinggang mengenakan selendang yang dililitkan. Rambut penari perempuan dikonde dan mengenakan tusuk konde dengan motif Cucuk Gunjung.

\section{Pelaksanaan Tari dibingi}

Pelaksanaan pergelaran tari dibingi yang merupakan bagian dari acara pernikahan adat di Kabupaten Pesisir Barat dilaksanakan di pihak keluarga laki-laki. Pihak keluarga mempelai perempuan dalam hal ini tidak ada sangkut pautnya dengan pelaksanaan tari dibingi. Dengan kata lain, pergelaran tari dibingi adalah murni diselenggarakan oleh pihak mempelai laki-laki. Meskipun demikian, pihak mempelai perempuan tidak dilarang untuk menonton ataupun menjadi bagian dari penari dibingi.

Tahapan pergelaran seni tari yang dilaksanakan dalam sebuah pesta pernikahan di Kabupaten Pesisir Barat menempatkan tari dibingi sebagai seni tari yang pertama kali dipentaskan. Setelah pergelaran tari dibingi selesai dilaksanakan, seni tari berikutnya adalah tari kipas. Dua buah tari berikutnya yang dilakukan dalam pesta pernikahan adat di Kabupaten Pesisir Barat yang dapat disebut sebagai selingan adalah Tari Pedang dan Tari Cabang (Trisula). Dipentaskan pula dalam pesta pernikahan tersebut sebuah atraksi pencak silat.

Tari dibingi yang dipergelarkan adalah harus menyesuaikan diri dengan apa yang telah disepakati dalam impun. Kesepakatan tersebut menyangkut gerak tari seperti kaki penari yang tidak boleh terlalu diangkat, demikian juga tangan penari yang harus mengikuti kesepakatan yang telah disetujui dalam impun tersebut. Jumlah penaripun turut dibahas dalam impun, apakah berjumlah dua orang ataupun empat orang. Durasi gelar tari dibingi juga ada dalam proses impun. Ada perbedaan antara masa dahulu dengan sekarang. Dahulu tari dibingi berdurasi lumayan panjang dan dilaksanakan harus pada malam hari, yaitu dimulai sekitar ba'da isya hingga pukul dua malam. yang dilaksanakan selalu pada malam hari. Oleh karena itu, dibutuhkan beberapa pasang penari Dibingi untuk memenuhi kuota yang telah disepakati dalam impun. Namun sesuai dengan perkembangan zaman, tari 
dibingi biasanya dilakukan dalam waktu yang cukup singkat yaitu sekitar lima menit saja.

Tari dibingi terdiri dari dua jenis, yaitu tari dibingi bebay (untuk perempuan) dan tari dibingi makat (untuk laki-laki). Gerakan Tari dibingi bebay berbeda dengan tari dibingi makat. Tari dibingi bebay biasanya dimulai dengan cara berjalan terlebih dahulu dari lokasi awal menuju lokasi pertunjukan. Gerak jalan penari perempuan dilakukan dengan cara seperti berjongkok sampai di titik yang disediakan kemudian dilanjutkan dengan duduk menghadap barisan ketua adat. Berlainan dengan tari dibingi bebay, Penari laki-laki dalam tari dibingi makat berjalan tegak dari posisi awal menuju titik yang disediakan kemudian baru duduk menghadap barisan ketua adat.

Kesepakatan dalam impun harus disertai dengan denda apabila ada pelanggaran dalam kesepakatan dari para ketua adat. Pelanggaran yang dianggap cukup berat akan didenda dengan cara membayar satu ekor kerbau jantan. Uniknya adalah bahwa yang membayar denda akibat pelanggaran tersebut adalah kelompok penari dibingi. Oleh karena itu, sebelum menyatakan siap untuk menari dibingi, Kelompok tari dibingi tersebut harus mempersiapkan akibat terburuk apabila ada salah seorang penari melakukan kesalahan. Hasil permusyawarahan dalam impun yang menyatakan pergelaran tari dibingi dapat dilaksanakan tentunya sudah dipersiapkan pula alat bayarnya, yaitu seekor kerbau jantan. Seekor kerbau jantan sebagai alat pembayaran denda tentunya berharga cukup mahal. Kelompok Tari dibingi yang tidak dikhususkan pada seseorang penari dari kalangan berekonomi berkecukupan memberikan kesan bahwa kelompok penari dibingi tersebut mementaskan sebuah tarian yang sama sekali tidak menguntungkan, atau bahkan merugikan. Ketidaksiapan membayar denda yang ditanggung oleh kelompok tari dibingi tersebut tentunya sudah dapat dipastikan.
Hal tersebut tentu akan membuat malu sang penyelenggara, yaitu pihak mempelai laki-laki apabila setelah adanya pelanggaran namun kelompok Tari dibingi tersebut tidak dapat membayar denda. Oleh karena itu, bisa saja pihak mempelai lakilaki telah mempersiapkan terlebih dahulu alat bayarnya, yaitu seekor kerbau jantan, namun penyerahan alat bayar tersebut dilakukan oleh kelompok tari dibingi. Walaupun sudah ada kepastian alat bayar, kesalahan atau pelanggaran dalam proses pergelaran tari dibingi sangat jarang terjadi mengingat alat bayar denda yang tergolong cukup mahal.

Kriteria kerbau jantan yang sah dalam pembayaran denda adalah kerbau jantan yang bertanduk dengan ukuran panjang yang juga disepakati dalam impun. Setelah proses pembayaran denda selesai, kerbau hasil denda tersebut kemudian disembelih. Sebagian hasil sembelihan tersebut diberikan kepada suku dan tuha. Suku dan tuha yang dimaksud adalah kepala adat yang bergelar Seibatin. Kepala adat memiliki bawahan yaitu suku dan tuha. Dahulu jumlah suku ada lima orang. Posisi suku sejajar dengan tuha yang berjumlah empat orang. Dengan demikian, sebagian daging kerbau hasil denda akan diberikan kepada 10 orang tersebut masing-masing seberat sekitar setengah hingga satu kilogram. Tugas penyembelihan kerbau diserahkan pada salah seorang panitia pesta pernikahan yang ditunjuk oleh Pang Tuha.

Setelah sebagian diberikan pada ketua adat beserta suku dan tuha, sisa daging kerbau yang ada kemudian dimasak biasanya dalam olahan sayur. Setelah masak biasanya akan menjadi bagian dari hidangan yang disajikan dalam nayuh.

Dibingi yang merupakan sebuah tari sakral memiliki unsur makna pada beberapa bagian gerak tari. Perihal makna dalam gerak tari menurut Khasanah dan Safitri (2009: 4) diibaratkan sebagai sebuah ungkapan maksud yang dituangkan melalui gerak yang distilir dengan tidak melupakan unsur estetika dan keindahan. 
Unsur gerak tari tidaklah melulu diisi oleh makna. Ada unsur gerak murni dalam tarian, yaitu gerak tubuh asli yang dilakukan tanpa mengandung arti atau makna, seperti gerak berjalan, berlari, dan sebagainya. Sementara untuk gerak tari yang mengandung makna misalnya gerak memanah, menghormat, memberi salam, mendayung, dan sebagainya.

Terkait dengan gerak maknawi seperti yang diungkapkan Khasanah dan Safitri, tari dibingi memiliki lima sesi atau bagian yang mengandung makna, yaitu:

1. Duduk hormat empat penjuru

2. Langkah tiga kakende

3. Nyawok

4. Kesor atau elang berbayang

5. Duduk hormat empat penjuru

Sesi pertama dan kelima, yaitu sesi duduk hormat empat penjuru diibaratkan sebagai sebuah ungkapan salam bertemu dan berpisah. Hal ini menandakan ada makna etika dalam adat Lampung yang diestetikan melalui gerakan-gerakan tari yang seolah-olah sedang memberi hormat. Sementara inti dari tari dibingi ada pada sesi kedua, ketiga, dan keempat.

Pengaruh adat Lampung yang dalam hal ini adalah dari Lampung Saibatin menandakan dalam tari dibingi memang merupakan sebuah tarian tradisional yang berpedoman pada adat istiadat. Hal ini diperkuat oleh Sodarsono (1978: 12) yang mendefinisikan tari tradisi. Dikatakan bahwa definisi tari tradisi merupakan bagian dari kelompok tari yang telah mengalami perjalanan sejarah yang lama ${ }^{4}$ dan selalu berpedoman pada adat dan tradisi yang distilirkan melalui unsur gerak tari.

${ }^{4}$ Istilah "lama" dalam sebuah perjalanan tari tradisi diperjelas oleh tim ahli Warisan Budaya Takbenda Direktorat Warisan dan Diplomasi Budaya, Kementerian Pendidikan dan Kebudayaan minimal 50 tahun atau setidaknya dua generasi telah terlewati.

\section{a. Duduk Hormat empat penjuru}

Setelah berada di arena pergelaran. Dua orang penari bersimpuh dan saling berhadapan dengan jarak sekitar satu meter. kedua telapak tangan masingmasing penari terbuka dan dirapatkan seolah sedang memberi salam. Tinggi posisi tangan saat dirapatkan adalah sejajar dengan kepala. Dengan tetap pada posisi bersimpuh, kedua penari kemudian bergerak menggeserkan badannya ke arah kanan kemudian keduanya saling membungkuk dengan posisi tangan seolah sedang memberi salam.

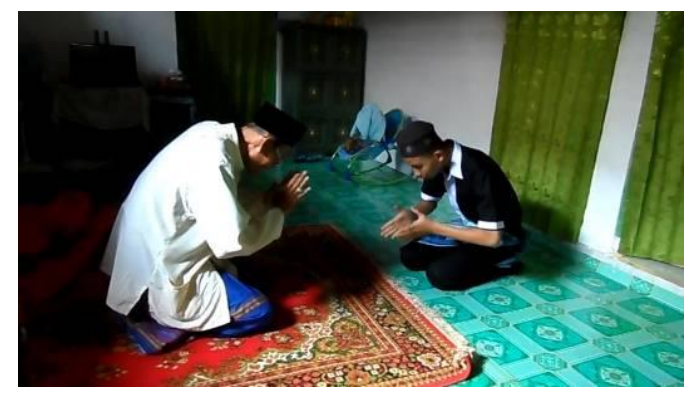

Gambar 7. Posisi memberi hormat

Sumber: Dokumentasi BPNB Jabar, 2018.

Setelah selesai melakukan sesi saling menghormat, kedua penari menggeserkan badannya kembali ke arah kanan sehingga keduanya kembali saling berhadapan. Selanjutnya, kembali keduanya saling memberi salam. Dengan demikian, gerak penghormatan dilakukan pada empat penjuru dan satu kali sesaat setelah melakukan penghormatan pada empat penjuru.

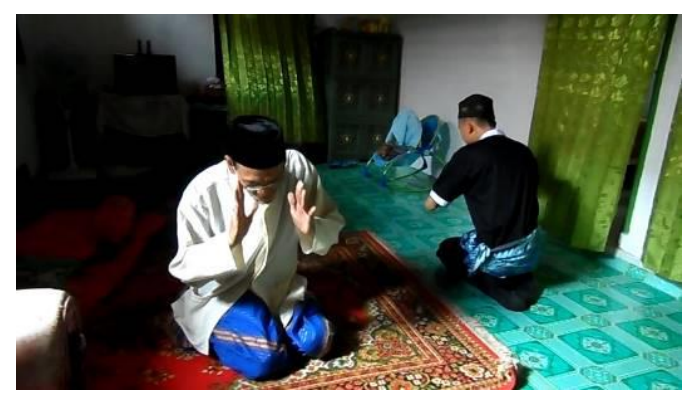

gambar 8 .

Sumber: Dokumentasi BPNB Jabar, 2018. 


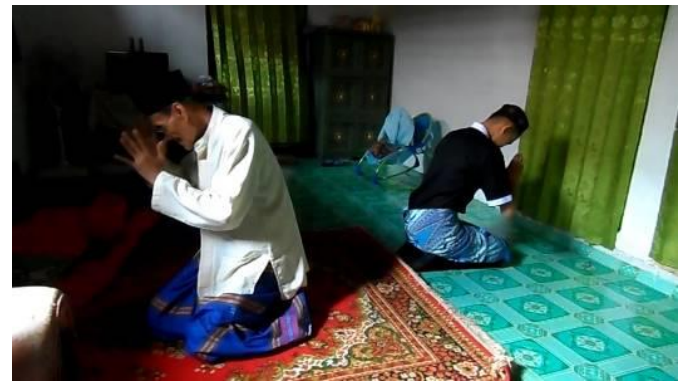

gambar 9.

Sumber: Dokumentasi BPNB Jabar, 2018.

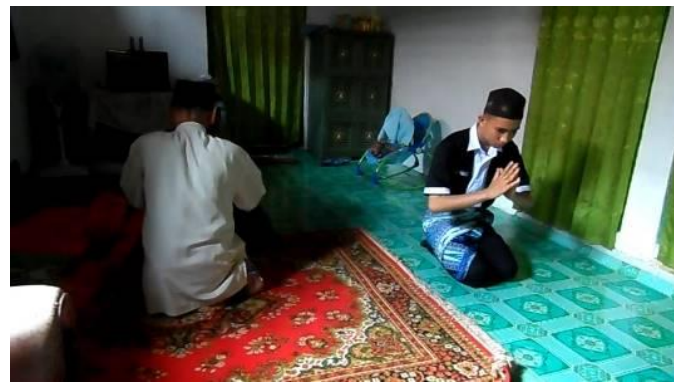

Gambar 10 .

Sumber: Dokumentasi BPNB Jabar, 2018.

Keterangan: Gambar 8-10, Penari menghadap ke kanan pada tiga arah mata angin sambil memberikan penghormatan (satu arah lagi saat penari saling berhadapan)

Jumlah posisi memberi hormat yang dilakukan empat penjuru. Pemberian hormat pertama dilakukan kepada barisan ketua adat. Penghormatan pada tiga penjuru mata angin diberikan sambil bergerak menghadap ke kanan adalah ditujukan pada penonton yang berstatus sebagai kerabat dan panitia. Setelah selesai sesi penghormatan, kedua penari kembali berdiri saling berhadapan dan memberi penghormatan.

\section{b. Langkah Tiga Kakende}

Setelah memberi penghormatan, dua penari sambil berhadapan langsung beranjak berdiri sambil mengangkat kaki kanan sejajar paha. Kedua tangan terangkat dengan telapak tangan setengah terbuka. Kemudian mengayunkan kedua tangan ke atas dan ke bawah sebanyak empat gerakan turun naik. Kaki kanan yang tadinya terangkat kemudian diturunkan lalu berganti kaki kiri yang diangkat sejajar paha. Kedua tangan tetap pada posisi gerakan turun naik. Setelah mengayunkan kedua angan beberapa kali kemudian kaki kiri diturunkan dan berganti kembali menjadi kaki kanan yang diangkat sejajar paha.

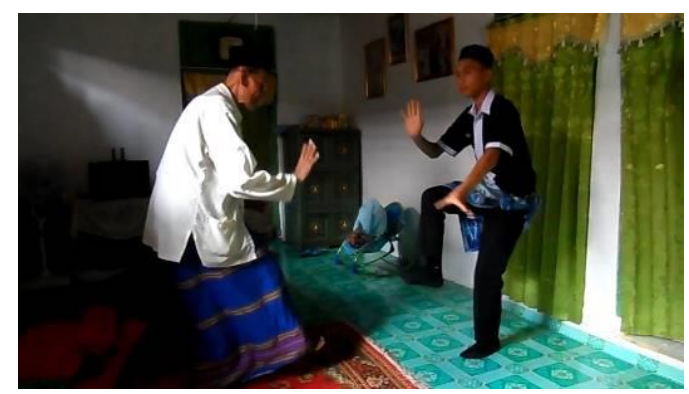

Gambar 11. Gerakan langkah tiga kakende Sumber: Dokumentasi BPNB Jabar, 2018.

Selesai kaki kanan terangkat sejajar paha, beberapa saat kemudian, kaki kanan diturunkan. Tangan sebelah kiri bergerak terangkat sejajar pundak dengan telapak tangan terbuka. Tangan kiri dibengkokkan $45 \%$ dengan telapak tangan terbuka dan bersentuhan dengan perut.

Gerak selanjutnya, kedua telapak tangan digerakan kekiri dan kekanan dan begitu juga dengan gerak kedua telapak kaki yang bergerak ke kiri dan ke kanan. Posisi telapak kaki bergerak dinamis sehingga letak posisi berdiri kedua penari menjadi bergerak melengkung ke arah kanan dengan tujuh kali gerak kedua telapak kaki kekiri dan kekanan.

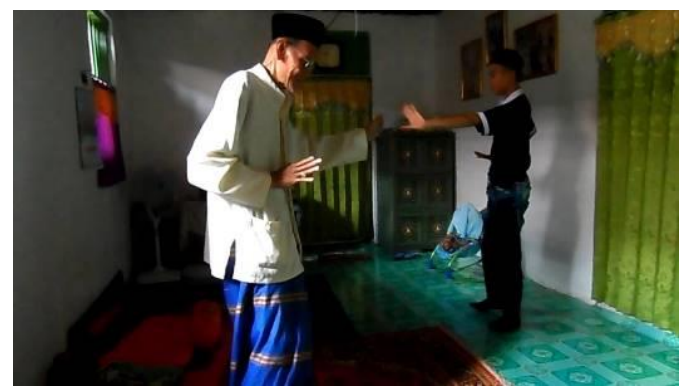

Gambar 12. Perpindahan posisi berdiri penari

Sumber: Dokumentasi BPNB Jabar, 2018.

Setelah tujuh kali gerak telapak kaki kekiri dan kekanan, posisi lutut kanan penari ditekuk sedikit dan begitu juga lutut 
kiri namun derajat tekukan yang lebih rendah dari kaki kanan. Kedua tangan penari terangkat lurus $45 \%$. Kedua jemari tangan dikuncupkan menghadap ke bawah.

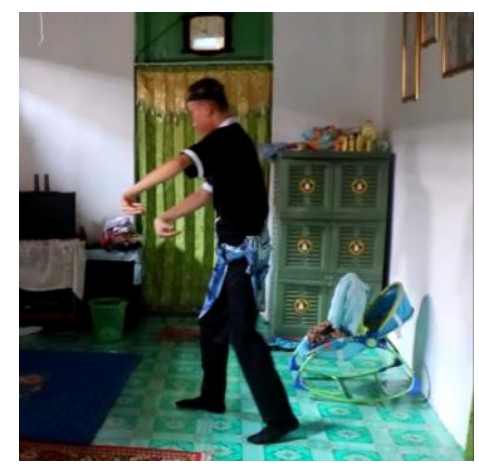

Gambar 13. Kedua jemari tangan dikuncupkan Sumber: Dokumentasi BPNB Jabar, 2018.

Selang dalam waktu sangat singkat kedua jemari tangan langsung dikembangkan. Telapak tangan kiri menghadap ke atas dan telapak tangan kanan menghadap ke bawah.

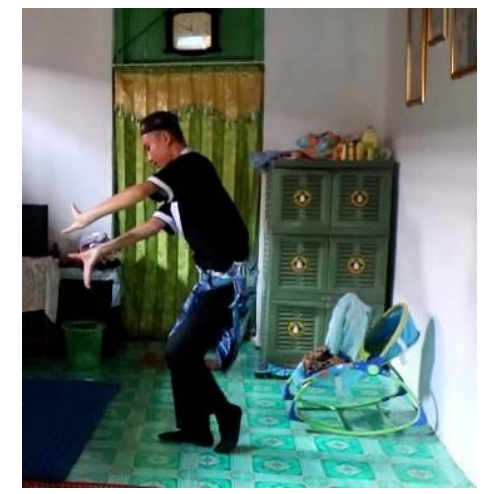

Gambar 14. Kedua jemari tangan dikuncupkan Sumber: Dokumentasi BPNB Jabar, 2018.

\section{c. Nyawok}

Setelah selesai posisi tersebut dilanjutkan dengan posisi yang dinamakan nyawok, yaitu posisi telapak tangan kanan yang tadinya terbuka bergerak gemulai mengangkat punggun telapak tangan kanan sambil menguncupkan kembali jemari. Siku tangan kanan dibengkokkan ke atas sambil membuka telapak tangan kanan ke atas. Gerakan tersebut kemudian langsung disambut dengan tangan kiri yang bergerak ke bawah tangan kanan sambil membuka telapak tangan kiri menghadap ke bawah.

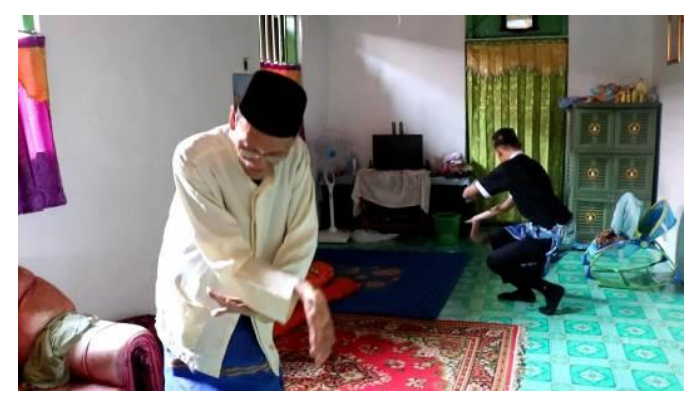

Gambar 15. Gerakan nyawok

Sumber: Dokumentasi BPNB Jabar, 2018.

Tangan kanan terus bergerak turun diikuti dengan gerak badan yang semakin membungkuk yang diikuti dengan tekukan kedua kaki. Tangan kiri tetap mengikuti sambil terus berada di bawah tangan kanan. Setelah dirasa cukup posisi membungkuk kedua tangan melakukan gerakan menyapu ke kanan dan ke kiri beberapa kali. Gerakan menyapu tersebut diikuti dengan gerakan turun naik kedua lutut secara dinamis.

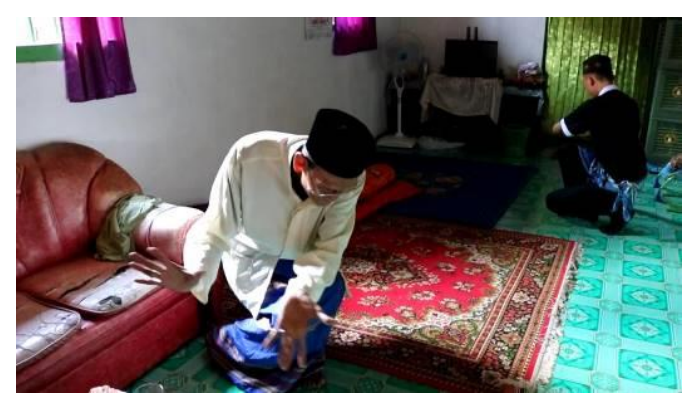

Gambar 16. Gerakan nyawok

Sumber: Dokumentasi BPNB Jabar, 2018.

Selesai gerakan nyawok, kedua penari berdiri kembali dengan posisi tangan kanan sejajar pundak diikuti posisi tangan kiri ditekuk $45 \%$. Telapak tangan kanan dan kiri terbuka dan menekuk $45 \%$ ke atas. 


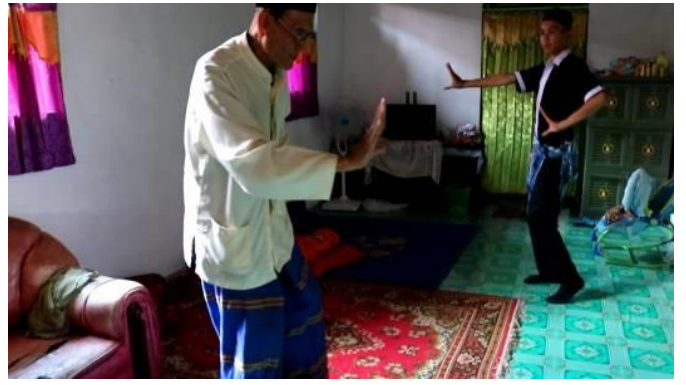

Gambar 17. Posisi berdiri setelah gerak nyawok Sumber: Dokumentasi BPNB Jabar, 2018.

Posisi penari kemudian bergerak ke arah kiri dengan cara menggerakkan kedua telapak kaki ke kiri dan kanan sedikit demi sedikit secara dinamis sebanyak tujuh langkah. Kedua telapak tangan yang terbuka juga melakukan gerak kekiri dan ke kanan seirama dengan gerak kedua telapak kaki. Pada posisi perhentian, gerakan nyawok kembali diulangi. Dengan demikian, dua penari melakukan gerakan nyawok pada dua arah mata angin.

Setelah melakukan nyawok, kedua penari kembali berdiri dengan posisi tangan kiri sejajar pundak sedangkan tangan kanan ditekuk $45 \%$. Kedua telapak tangan ditekuk ke atas $45 \%$ dengan posisi terbuka. Kedua penari kemudian bergerak ke arah kanan dengan cara mengeser telapak kedua kaki ke kiri dan ke kanan. Setelah pada posisi berhadapan, kedua tangan diangkat hampir sejajar pundak lalusiku ditekuk ke dalam. Posisi telapak tangan setengah terbuka dan menghadap ke bawah.

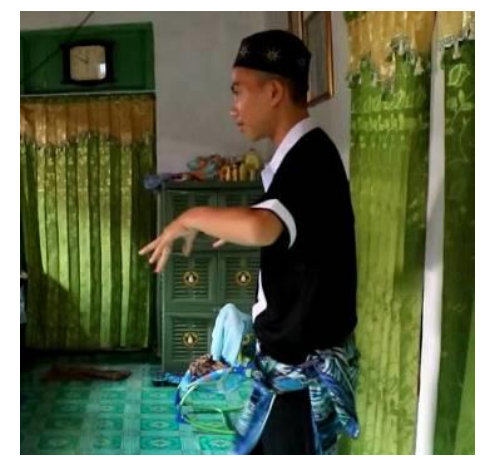

Gambar 18. Posisi pada saat berhadapan Sumber: Dokumentasi BPNB Jabar, 2018.
Beberapa saat kemudian, kedua telapak tangan terbuka dan menghadap ke arah penari di depannya. Kaki kanan bergerak satu langkah ke depan diikuti kaki kiri. Kedua telapak tangan kedua penari kemudian saling merapat dan dengan posisi kedua kaki berdiri $90 \%$.
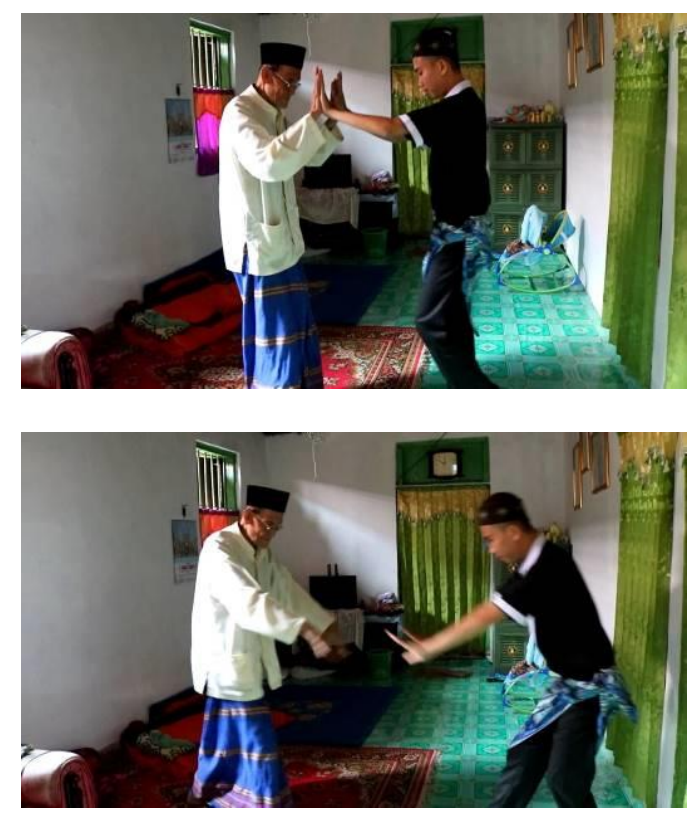

Gambar 19 dan 20. Posisi kedua tangan kedua penari yang saling merapat kemudian saling melepas

Sumber: Dokumentasi BPNB Jabar, 2018.

Posisi kedua tangan kedua penari yang rapat telapak tangan kemudian diangkat bersamaan dan diikuti dengan kaki kiri yang melangkah satu kali ke belakang sambil diikuti pula dengan kaki kanan sambil bersiap melakukan gerak kesor atau elang berbayang.

\section{d. Kesor atau Elang Berbayang}

Elang dalam Sesi elang berbayang merupakan bagian dari gerak tari yang memang mirip dengan gerakan kepak sayap burung elang saat sedang memburu mangsa. Sosok elang, atau Kenui dalam Bahasa Lampung, merupakan jenis unggas yang sudah melegenda dan sekaligus menjadi salah satu mitos yang menjadi dasar terbaginya masyarakat Lampung 
menjadi dua sub adat, yaitu Adat Lampung Pepadun, dan Saibatin.

Gerakan kesor atau elang berbayang sebenarnya terdiri dari dua bagian, yaitu kesor dan elang berbayang. Namun demikian, kedua gerakan ini harus berdampingan dan menjadikannya sebagai satu sesi gerak.

Gerakan ini dilakukan setelah sesi nyawok, yaitu dengan cara melepas dan memundurkan gerak kaki penari setelah posisi kedua tangan kedua penari saling merapat. Setelah itu posisi kedua tangan penari bergerak turun lurus $90 \%$ kemudian langsung diangkat bersamaan dengan telapak tangan terbuka. Posisi tangan kiri sejajar pundak menghadap ke samping kiri, sementara siku tangan kanan ditekuk dan menghadap ke atas gerakan ini dilakukan bergantian sambil memutar kedua telapak tangan ke ke kiri dan ke kanan. Gerakan ini disertai dengan gerakan kedua telapak kaki yang bergeser dinamis sehingga menggerakan badan penari memutar ke arah kanan.

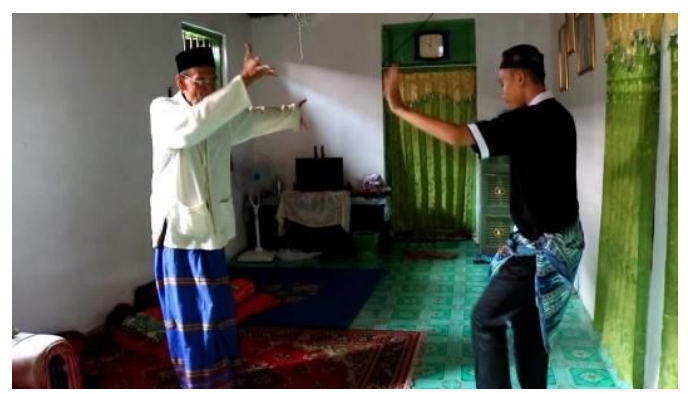

Gambar 21. Posisi pada saat memutar ke arah kanan

Sumber: Dokumentasi BPNB Jabar, 2018.

Setelah posisi putar penari berada 180 derajat dari posisi semula, kedua penari kemudian bergerak kearah kiri dengan cara menggeser kedua telapak kaki secara dinamis. Kedua tangan melakukan gerakan seperti halnya pada saat memutar ke arah kanan, namun bergerak sebaliknya karena gerak penari mengarah ke kiri.

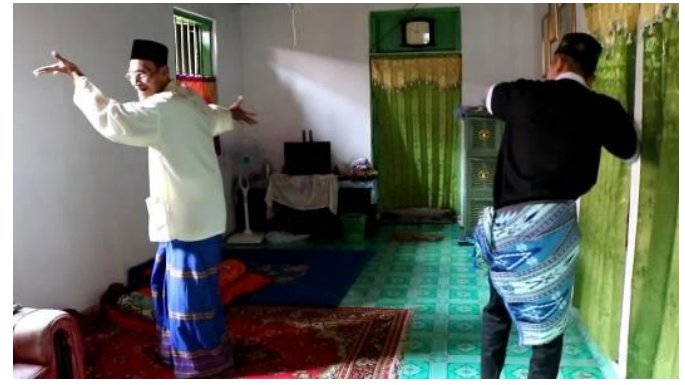

Gambar 22. Posisi tangan dan gerak badan penari saat memutar ke kiri

Sumber: Dokumentasi BPNB Jabar, 2018.

Gerakan badan yang berputar ke kanan dan ke kiri dalam sesi gerak kesor atau elang berbayang dilakukan sebanyak empat kali. Selesai melakukan sesi gerak kesor atau elang berbayang, kedua penari kembali berhadapan dan saling merapatkan merapatkan kedua telapak tangan. Sesi selanjutnya adalah kembali melakukan gerakan langkah tiga kakende dan nyawok sebanyak tiga kali. Gerakan kesor atau elang berbayang kembali diulang sebanyak tiga kali namun tidak diiringi dengan gerakan merapatkan kedua telapak tangan kedua penari terlebih dahulu seperti pada sesi kesor atau elang berbayang sebelumnya.

\section{e. Duduk hormat empat penjuru}

Setelah melakukan gerak kesor atau elang berbayang maka berakhirlah gerak tari dibingi. Akhir gerak tari dibingi ditutup dengan gerak atau sesi duduk hormat empat penjuru dengan gerak tari yang sama seperti pada sesi pertama.

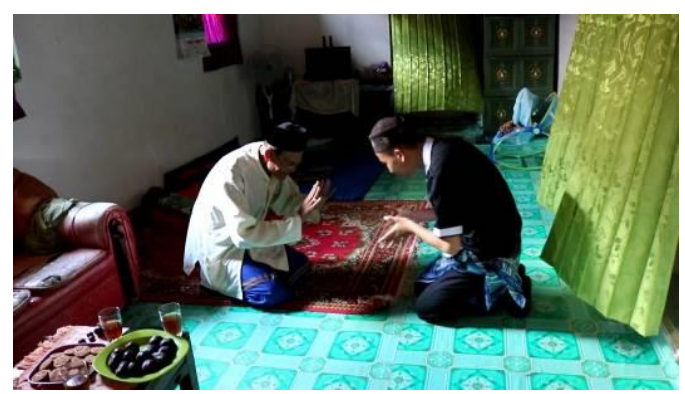

Gambar 23. Posisi pada saat memutar ke arah kanan

Sumber: Dokumentasi BPNB Jabar, 2018. 
Kelima sesi dalam tari dibingi saat dipergelarkan dalam pertunjukan adat seperti dikemukakan di atas memerlukan waktu yang cukup lama, sedangkan pada kondisi kekinian cukup memerlukan lima menit saja. Hal ini dapat saja terjadi mengingat kelima sesi dalam tari dibingi adalah seperti yang dikemukakan oleh Soeharto (1985: 37) bahwa sesi atau motif dalam tari dapat dikembangkan dan divariasikan secara bersamaan. Durasi waktu dalam motif juga dapat diakselerasikan apakah menjadi lebih cepat atau menjadi lebih lambat. Oleh karena itu, sajian tari dibingi sebenarnya dapat menjadi sebuah tontonan yang tentu saja dikolaborasikan terlebih dahulu agar tampak lebih menarik bagi mata penonton saat ini. Namun demikian, maksud tersebut tentu saja berpulang kembali pada persetujuan para tetua adat Lampung pada tari sakral yang bernama dibingi.

\section{PENUTUP}

Pergelaran tari dibingi pada mulanya tersebar tidak hanya di Pekon Penengahan saja. Wilayah tari dibingi tersebar mulai dari perbatasan dengan Provinsi Bengkulu hingga ke Ujung Belimbing (sekarang berada dalam wilayah administratif Kecamatan Bengkunat Belimbing). Saat ini Tari dibingi sudah sangat jarang dilakukan. Salah satu penyebabnya adalah bahwa tari dibingi masih dianggap sebagai tari sakral dalam adat setempat. Dengan demikian, aturan adat baik sebelum ataupun sesudah pergelaran tari dibingi wajib dilaksanakan. Apalagi Tarian ini masih belum boleh dipergelarkan sebagai sebuah seni pertunjukan.

Tari dibingi merupakan seni tari tradisional terancam punah yang ada di Kabupaten Pesisir Barat Provinsi Lampung. Dengan hanya menyisakan satu orang maestro seni, sudah sepatutnya ada perhatian dari instansi terkait yang serius menangani upaya pelestarian sebuah kesenian tradisional yang menjadi bagian dari kekayaan budaya Kabupaten Pesisir Barat Provinsi Lampung.

Terima kasih :

Bapak HY (Ds. Penengahan Laay, Kec. Karya Penggawa, Kab. Pesisir Barat)

\section{DAFTAR SUMBER}

\section{Makalah, Laporan Penelitian, Skripsi, Tesis, dan Jurnal}

Ratih, Endang E.W, 2001

"Fungsi Tari sebagai Seni Pertunjukan", dalam Harmonia, Vol.2 No.2/MeiAgustus 2001

Rosyadi, 2016

"Kesenian Gondang sebagai Representasi Tradisi Masyarakat Petani di Jawa Barat", dalam Patanjala Vol. 8 No. 3 September 2016: 397- 412.

Sabaruddin. 2012.

Pepadun dan Saibatin/Pesisir. Jakarta. Buletin Way Lima Manjau.

Susanti, B. M. 2000

"Penelitian Tentang Perempuan Dari Pandangan Androsentris ke Perspektif Gender". Dalam EKSPRESI Dari Bias lelaki menuju Kesetaraan Gender Jurnal ISI Yogyakarta.

\section{Buku}

C. Barth. 1970.

Theologi Perjanjian Lama, Jakarta: BPK Gunung Mulia.

Khasanah dan Safitri. 2009.

Tari-tarian Nusantara. Jakarta: Azka Press.

R. Soedarsono. 1988.

Kamus Istilah Teologi, Jakarta: BPK Gunung Mulia.

Soedarsono. 1978.

Pengantar Pengetahuan dan Komposisi Tari. Yogyakarta: Akademi Seni Tari Indonesia.

Suharto. 1985.

Komposisi tari sebuah petunjuk praktis bagi guru: (terj. Jacqueline Smith). Yogyakarta: Ikalasti Yogyakarta.

Tim Penyusun Kamus Pusat Bahasa, 2008 Kamus Bahasa Indonesia, Jakarta: Pusat Bahasa. 
Tim Penyusun Kabupaten Pesisir Barat dalam Angka 2016

Kabupaten Pesisir Barat dalam Angka Tahun 2016, Krui: Dinas Kependudukan dan Pencatatan Sipil Kabupaten Pesisir Barat.

Waluyo, Harry, 2009

Practical Handbook for Inventory of Intangible Cultural Heritage of Indonesia, Jakarta: Ministry of Culture and Tourism in collaboration with UNESCO Office.

\section{Internet}

Saliwa, "Tata Titi Pakaian Adat Sekala Brak", dalam http://www.kerajaansekalabrak. com/2017/04/aturan-pakaiantradisional-sekala-brak.html tanggal 4 April 2017 